\title{
Neurovascular Reactivity in Tissue Scarring Following Cerebral Ischemia
}

\author{
Daniel Manrique-Castano ${ }^{1,2} \bullet$ Ayman ElAli1,2 \\ ${ }^{1}$ Neuroscience Axis, Research Center of CHU de Québec - Université Laval, Québec City, \\ QC, Canada; ${ }^{2}$ Department of Psychiatry and Neuroscience, Faculty of Medicine, \\ Université Laval, Québec City, QC, Canada
}

Author for correspondence: Ayman ElAli, Department of Psychiatry and Neuroscience, Faculty of Medicine, Université Laval, Quebec City, QC, Canada. E-mail: ayman.el-ali@crchudequebec.ulaval.ca

Cite this chapter as: Manrique-Castano D, ElAli A. Neurovascular reactivity in tissue scarring following cerebral ischemia. In: Pluta R, editor. Cerebral Ischemia. Brisbane (AU): Exon Publications; 2021. Online first Aug 18.

Doi: https://doi.org/10.36255/exonpublications.cerebralischemia.2021.neurovascularreactivity

\begin{abstract}
Tissue scarring upon cerebral ischemia entails a cascade of multifaceted cellular and molecular mechanisms that govern the remodeling of the neurovascular unit, which integrates neuronal, glial, and vascular functions. The process encompasses inflammation, Glial and vascular reactivity, and neuronal remodeling. In this chapter we cover three major aspects involved in tissue scarring after cerebral ischemia. First, we outline the primary cellular mechanisms underlying glial scar formation, emphasizing on the interactions between astrocytes, microglia, and mural cells, including pericytes and fibroblasts at the injury core and perilesional areas. Next, we address the key routes of extracellular matrix deposition by reactive and fibrogenic cells, including proteoglycans, tenascins, fibronectin, and collagen. Finally, we discuss the promises and challenges of manipulating tissue scarring as a strategy to promote brain structural remodeling and neurological recovery.
\end{abstract}

Keywords: brain remodeling; cerebral ischemia; extracellular matrix; fibrotic scar; glial scar

In: Cerebral Ischemia. Pluta R (Editor). Exon Publications, Brisbane, Australia. ISBN: 978-0-6450017-9-2; Doi: https://doi.org/10.36255/exonpublications. cerebralischemia.2021

Copyright: The Authors.

License: This open access article is licenced under Creative Commons Attribution-NonCommercial 4.0 International (CC BY-NC 4.0) https://creativecommons.org/licenses/by-nc/4.0/ 


\section{INTRODUCTION}

Neuroglial response to injury was initially reported in 1927 by Pío del Río Hortega and Wilder Penfield in the founding article "Cerebral cicatrix: the reaction of neuroglia and microglia to brain wounds" (1). Those detailed observations were the groundwork for elucidating the pathophysiology of central nervous system (CNS) response to injury, as well as the complex mechanisms involved in tissue healing and replacement. From then on, experimental evidence compiled from several CNS diseases (2), including traumatic brain injury (TBI) (3), spinal cord injury (SCI) (4), and cerebral ischemia (5) denotes the importance of neuroglial reactivity in the pathobiology of CNS injuries.

Cerebral ischemia is a multifaceted injury comprising three different phases: (i) cell death and neuroinflammation, (ii) tissue replacement, and (iii) tissue remodeling (6). Diverse experimental models, including middle cerebral artery occlusion (MCAo), photothrombosis, and craniectomy with direct vessel occlusion indicate that neuroglial response takes place through all stroke phases and broadly determines its evolution and the prospects of neurological recovery (7). One of the pivotal consequences of glial reactivity is acute and chronic tissue scarring (6) that comprises the functional reorganization of several components of the neurovascular unit (NVU), including endothelial cells, pericytes $(8,9)$, polydendrocytes/ neural/glial antigen (NG)2+(10), astrocytes (11), and microglia (12). This cell arrangement known as the glial scar is accompanied by a vast deposition of glial and neuronal-derived extracellular matrix (ECM) proteins that constitute a molecular compartment, namely the fibrotic scar (13). Shortly after the injury, these ECM substrates influence neuroinflammation, glial reactivity, and neuronal survival (14), and participate in debris removal and tissue regeneration in later stages (15).

Notably, the contribution of vascular cells, namely endothelial and mural cells, to tissue scarring has been recognized in recent years (9). Current perspectives in the field of CNS injuries emphasize that platelet-derived growth factor receptor (PDGFR) $\beta^{+}$mural cells are essential to regulate the proliferation, fate, migration, and metabolism of glial scar-forming cells (16-18). In addition, the proliferation and migration of PDGFR $\beta^{+} /$fibroblast-like cells are associated with the presence of specific ECM proteins in the fibrotic scar, which provides the tissue peculiar properties to favor structural remodeling $(19,20)$. In this chapter, we highlight the key regulatory mechanisms underlying the structuring of glial and fibrotic scars in the context of cerebral ischemia and discuss the promises and challenges of scarring manipulation to facilitate recovery.

\section{PERICYTES AS GLIAL ACTIVATORS AND SCAR-FORMING CELLS}

Even though microglia have long been considered the first responders to CNS injury and modulators of the innate immune responses $(21,22)$, emergent evidence suggests that PDGFR $\beta^{+}$mural cells, which comprise pericytes, constitute the initial inflammatory mediators that prime acute glial activation (23). PDGFR $\beta^{+}$ 
cells are a heterogeneous population of perivascular cells embedded within the basement membrane (BM) of arterioles/capillaries (Figure 1) that closely communicate with endothelial cells and astrocytes to regulate diverse vascular functions, including blood-brain barrier (BBB) permeability, vascular stability, inflammation, angiogenesis and neurogenesis $(24,25)$.

Multiple experimental studies indicate that PDGFR $\beta^{+}$mural cells are highly reactive to inflammatory signals/alarmins derived by dysfunctional cells resulting from ischemia. Their response repertoire includes the modulation of tolllike receptor (TLR)4 (26) and nuclear factor kappa B (NF-kB) (27) pathways, PDGF-B/PDGFR $\beta$ pathway, transforming growth factor (TGF)- $\beta 1 / \mathrm{TGF}-\beta R 2$ pathway (28), activin receptor-like kinase (ALK)5/SMAD-2/3 pathway, and integrin- $\alpha$ v complexes $(28,29)$ (Figure 2$)$. The activation of PDGFR $\beta^{+}$cells triggers a first wave of inflammatory signals that prime neuroglial response (3032). Specifically, single-cell RNA sequencing (RNA-seq) and in situ hybridization (ISH) studies have demonstrated that PDGFR $\beta^{+}$mural cells are the primary
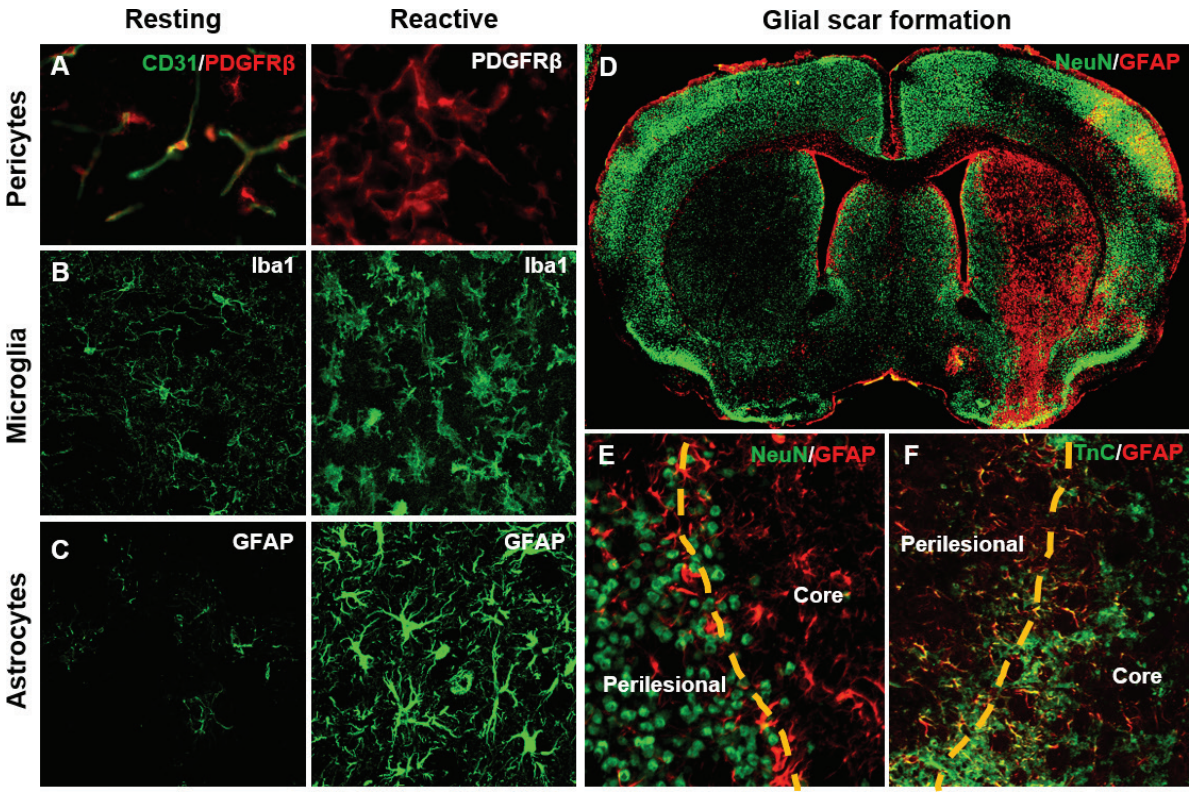

Figure 1. Multicellular reactivity and glial scar formation. A, In the healthy brain, PDGFR $\beta^{+}$mural cells wrap the vasculature (green) to regulate neurovascular functions. Following ischemia, reactive PDGFR $\beta^{+}$pericytes detach from the vascular wall and migrate towards the brain parenchyma to adopt fibrogenic properties (×63). B, Microglia are highly ramified cells that react to ischemic insult by upregulating proteins like lba1 and CD45, while adopting amoeboid morphologies, and populating the injury core as integral building blocks of the glial scar $(\times 63)$. C, Reactive astrocytes are featured by prominent upregulation of GFAP and prominent cell hypertrophy $(\times 63)$. D, Following ischemia, reactive astrocytes invade the injury core, where no $\mathrm{NeuN}^{+}$(healthy) cells are present $(\times 10)$. E, The cell barrier separates the perilesional tissue to prevent the infiltration of inflammatory signaling to the healthy tissue comprising vulnerable cells that could recover $(\times 20)$. F, This cell alignment is accompanied by a molecular barrier of fibrotic scar-forming cells as $\mathrm{TnC}$ that exerts immunoregulatory and healing roles $(\times 20)$. 


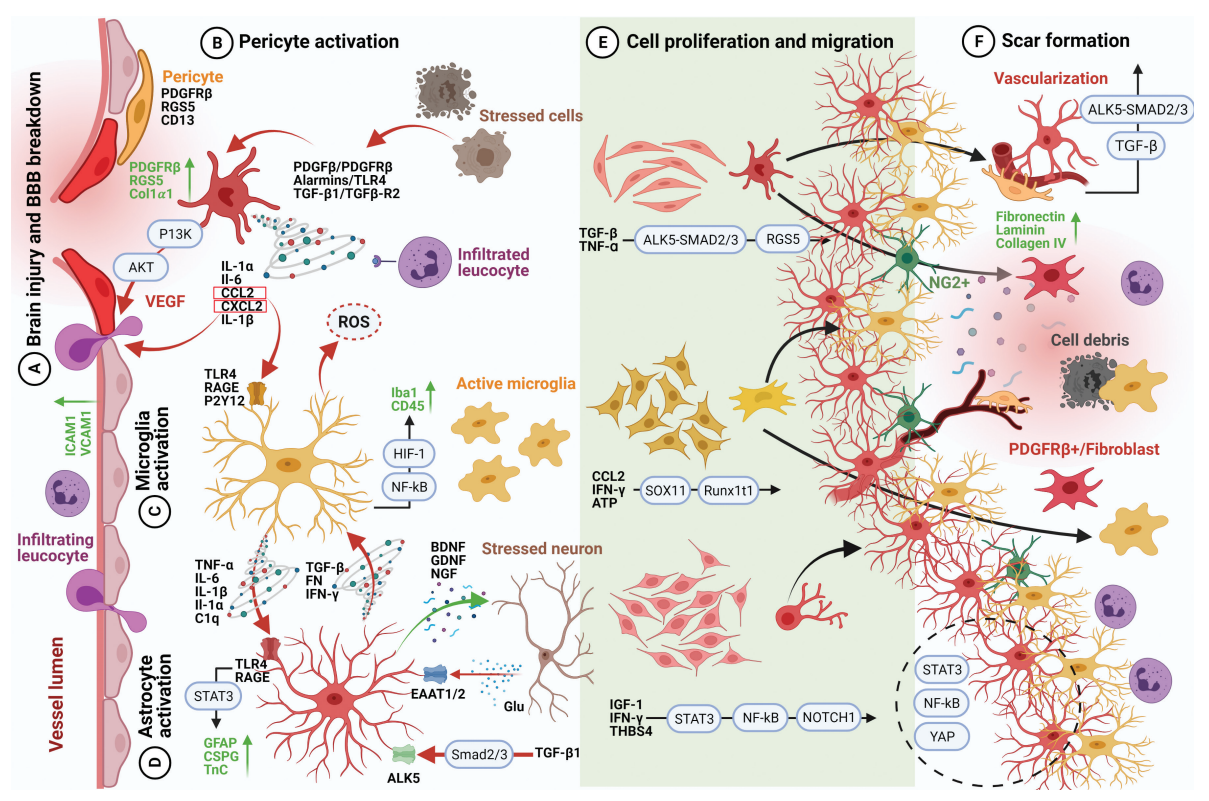

Figure 2. Cellular and molecular pathways implicated in glial scar formation. A, Brain injury upon ischemia leads to blood-brain barrier breakdown and neuroinflammation. B, Mural cells, including pericytes, are among the first cells at the neurovascular unit to respond to injury by secreting diverse inflammatory mediators that trigger glial activation and leukocyte recruitment. C, Microglia respond to pericyte-derived cytokines and damaged cells by adopting an amoeboid morphology to facilitate migration and phagocytosis, and by releasing a second wave of inflammatory cytokines that sustain the inflammatory loop and initiate astrocyte reactivity. D, Astrogliosis, or astrocyte activation, entails the upregulation of glutamate receptors to modulate neuronal excitotoxicity and the deposition of numerous ECM proteins that establish the structure the fibrotic scar. E, Following the initial responses, numerous cells at the neurovascular unit, including PDGFR $\beta^{+}$pericytes, microglia, and astrocytes proliferate in situ or in the neurogenic zones, and migrate towards the injury core to form the glial scar. F, The glial scar is a stratified arrangement of neuroglia and fibrotic cells that separate the damaged from healthy tissue. This structure relies on the metabolic support offered by endothelial/pericyte-driven revascularization.

sources of CC-chemokine ligand (CCL)-2, also known as monocyte chemotactic protein (MCP)-1 (33), a well-known alarmin that influences the immune response and glial reactivity shortly after injury (33-35). Additional evidence donates that mural cells are relevant sources of nicotinamide adenine dinucleotide phosphate (NADPH) oxidase (NOX)-4, a molecule tightly linked to the generation of reactive oxygen species (ROS) by microglia, which act as a potent inflammation amplifier (36).

By this means, the initial stimulation of PDGFR $\beta^{+}$cells prompt the secretion of additional pro-inflammatory cytokines by various cellular components of the NVU, namely interleukin (IL)- $1 \beta$, tumor necrosis factor (TNF)- $\alpha$, IL-3, IL-9, ILl-3, IL-6, and chemokines, such as CCL-3, CCL-4, CCL-5, MCP-1, and the macrophage inflammatory protein (MIP)-1 (30-32). Collectively, these substrates shape long-standing inflammatory loops that are decisive for the recruitment of 
peripheral leukocytes and the formation of the glial scar by reactive neuroglia and fibroblast-like cells in the injury site.

Apart from the secretion of inflammatory signals, reactivity of PDGFR $\beta^{+}$cells also involves the upregulation of specific mural/fibrosis markers, including PDGFR $\beta$ (Figure 1), desmin, NG2 (37), collagen type I alpha 1 chain (COL1- $\alpha 1$ ), and the regulator of G-protein signaling (RGS)5 (33) that are associated with cell proliferation, migration, and secretion of scar-forming proteins (37-39). Some of these markers have been identified as crucial players in the context of ischemic lesions. More precisely, PDGFR $\beta$ has been associated with neuroprotective effects (decreased infarct size/edema) in acute and chronic phases following ischemia, as well as enhanced cell proliferation, angiogenesis, and deposition of scar-forming molecules like fibronectin and collagen (40-42). Besides, the upregulation of RGS5 facilitates cell detachment from the vascular wall and the subsequent migration of mural cells towards the ischemic core (Figure 2). Interestingly, in contrast to PDGFR $\beta$-deficient mice, RGS5-deficient animals exhibit enhanced vascular density, mural cell coverage, and tight junction (TJ) integrity $(43,44)$, denoting that mural cell migration provokes a contextualized weakening of vascular function in lesioned regions and favors tissue scarring.

Experimental evidence suggests that while a group of PDGFR $\beta^{+} / \mathrm{NG}^{+}$mural cells remains at the lesion borders (45), other migrating PDGFR $\beta^{+} /$glial highaffinity glutamate transporter (GLAST) ${ }^{+}$cells (type A pericytes) give rise to scarforming fibroblast-like cells that become a key source of collagen, laminin, fibronectin, and neurocan in the lesion core $(19,20,46-48)$. Deposition of these proteins is highly dependent on TGF- $\beta 1(49,50)$ and Wnt/ $\beta$-catenin pathways (47) (Figure 3), impacting tissue elasticity and stiffness, and thus influencing key pathophysiological cascades such as glial reactivity $(51,52)$, cell differentiation (53), and neurite outgrowth $(54,55)$. Notably, evidence from cerebral ischemia has revealed that reactive PDGFR $\beta^{+} /$fibroblast-like cells influence astrocyte reactivity in perilesional regions and promote oligodendrocyte precursor cells (OPC) differentiation to favor post-stroke myelination (40).

Furthermore, the response of PDGFR $\beta^{+}$mural cells to cerebral ischemia is also associated with revascularization of the injured area, which is required for the migration of newborn neurons (56) or the proper organization of the glial scar $(9,17,57)$ (Figure 2). The evidence indicates that this process occurs due to the interchange of mural and endothelial cells through TGF- $\beta$ and the TGF $\beta-R 2 /$ ALK5-SMAD-2/3 signaling pathway (58), or by connexin-43, N-cadherin, and prostaglandin E2 $(\mathrm{EP} 1 / 4)$ receptors $(59,60)$ that facilitate the structuring of new blood vessels and an adequate BM production, including fibronectin, laminin, and collagen IV (61).

Collectively, the previous reports offer substantial grounds to consider PDGFR $\beta^{+}$mural cells as important responders to cerebral ischemia (62). First, they act as inflammatory amplifiers and demarcate the injured territory to mediate glial reactivity and the recruitment of resident and peripheral macrophages in the infarcted area. Next, they modulate tissue scarring by forming cell networks implicated in the revascularization of the injured tissue and the deposition of fibrotic proteins in the infarct core. 


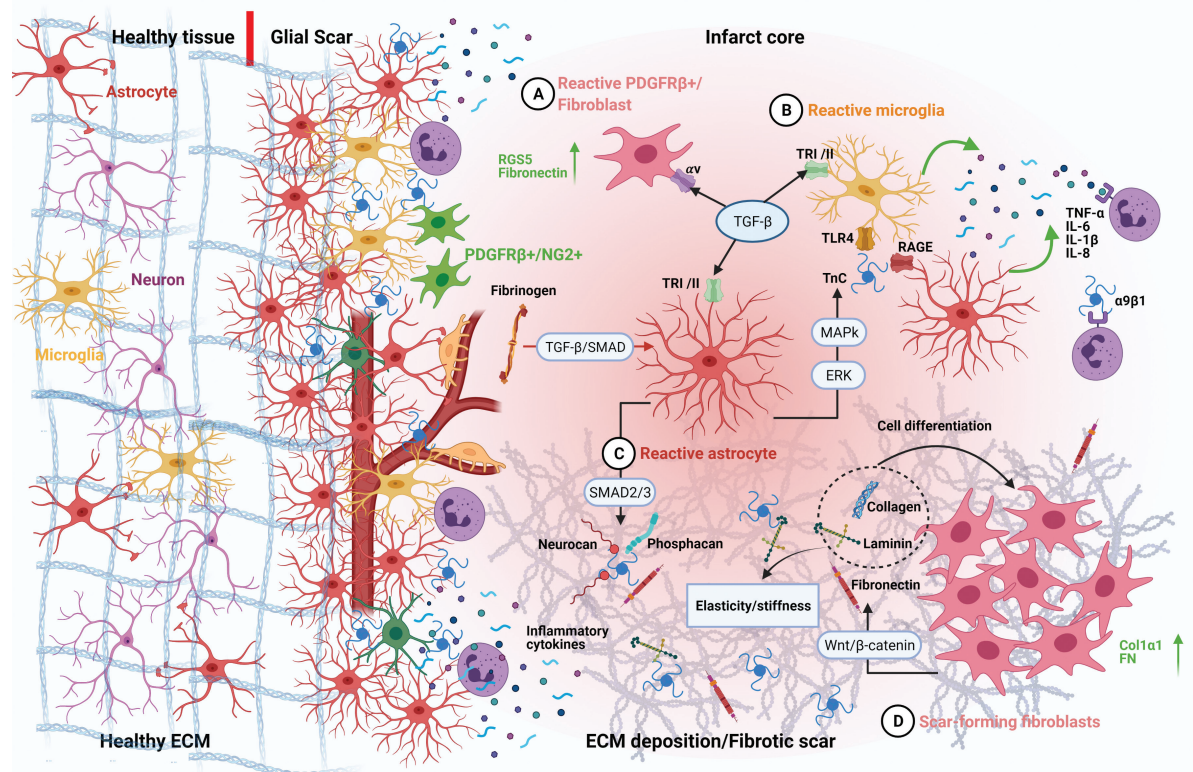

Figure 3. Fibrotic scar deposition by reactive neurovascular unit cells. Glial scar formation entails the deposition of fibrotic molecules at the injury core to prevent the infiltration of peripheral leukocytes and inflammatory signaling into the healthy tissue. A, Mural PDGFR $\beta^{+}$ cells give rise to scar-forming fibroblasts that migrate to the injury core and become a major source of fibrotic molecules. B, At the injury site, microglia respond to multiple signaling, including TGF- $\beta$ and TnC to modulate the recruitment of peripheral immune cells and astrocyte activation. C, In turn, reactive astrocytes constitute the primary reservoirs of scar-forming TnC as well as CSPGs, which exert immunoregulatory roles and facilitate tissue replacement. Due to its high ligand capacity, $\mathrm{TnC}$ allows determining the action of distinct ECM molecules at the fibrotic scar. D, The abundant deposition of fibrotic proteins, including collagen, laminin, and fibronectin by fibroblast-like cells deriving from PDGFR $\beta^{+}$ cells that invade the lesion core, determines tissue elasticity and stiffness, and thus control neuronal plasticity inhibition or promotion balance.

\section{MICROGLIAL ACTIVATION AND INNATE IMMUNE RESPONSE}

Microglial activation implicates neuroinflammatory signaling that broadly defines immune cell infiltration, glial response, and tissue repair (63). Microglia reactivity is triggered promptly after ischemia by numerous mechanisms, such as BBB disruption, neuronal hyperactivity/excitotoxicity, and inflammatory mediators secreted by various cells, including reactive PDGFR $\beta^{+}$mural cells $(64,65)$. These substrates bind to TLR, advanced glycation end products (RAGE), or P2Y12 receptors to sustain numerous neuroinflammatory loops (65-67), evidenced by the expression of hypoxia-inducible factor (HIF)- $1 \alpha$ and microglial activation markers, such as ionized calcium-binding adapter molecule (Iba-1), CD45, CD68, CD206, MCP-1, and the neurotrophic factor insulin-like growth factor (IGF)-1 
(68-70) (Figure 1). This microglial response is followed by the secretion of proinflammatory cytokines, including TNF- $\alpha$, IL-1 $\beta$, IL-6, NO, ROS (71-73) that jointly amplify the neuroinflammatory signals initiated by pericytes and fosters the recruitment of peripheral immune cells that exacerbate glial reactivity (Figure 3). Furthermore, microglial activation after ischemia involves morphological changes from highly ramified towards amoeboid-shaped cells $(68,74)$ that facilitate cell migration (75) and phagocytosis in the injury core (76) (Figure 1). Transcriptomic analyses of "resting" and "active" microglia have revealed that ramified cells express low levels of cytokines and chemokines, as well as genes related to neuronal maturation and synaptic integrity. In contrast, amoeboid cells exhibit prominent transcription factors involved in migration, proliferation, and differentiation, such as SRY (sex determining region Y)-box 4 (SOX4), SOX11, and Runt-related transcription factor 1 (RUNX1) partner transcriptional co-repressor 1 (Runxlt1) (77).

In experimental models of SCI, reactive microglia are essential components of the glial scar (12) and are involved in a bi-directional interaction with neighboring reactive astrocytes $(78,79)$. On the one hand, it has been found that microglialderived TNF- $\alpha$, IL- $1 \alpha$, complement (C) $1 \mathrm{q}$, and IL- 6 cytokines determinedly shape the astrocytic pro-inflammatory profile via TLR4 and RAGE receptors (80-82) (Figure 2). Likewise, whole-genome expression profiling of cultured astrocytes has revealed that exposition to inflammatory mediators secreted by microglia like TGF- $\beta 1$ and IFN- $\gamma$ alters the transcriptional pathways of G-proteincoupled receptors (GPCRs) associated with cell injury and proliferation, such as P2RY1, CXCR4, and adrenoceptor alpha (ADRA)2A (83). On the other hand, the evidence suggests that reactive astrocytes can modulate microglial activation, proliferation, and migration by different pathways, including inflammatory mediators such as IFN- $\gamma$, ATP, nitric oxide (NO), IL-6, IL-1 $\beta$, and IL-lra (81, 84, 85 ), or by the secretion of ECM proteins like fibronectin/ $\beta 1$ integrin pathway (86) or tenascin-c (TnC) $(87,88)$ (Figure 2). Conversely, astrocyte-derived TGF- $\beta$ inhibits microglial response to lipopolysaccharide (LPS) and IFN- $\gamma$ and reduces the subsequent secretion of inflammatory mediators (89).

Findings from cerebral ischemia models indicate that $\mathrm{CX} 3 \mathrm{C}$ chemokine receptor $(\mathrm{CX} 3 \mathrm{CR}) \mathrm{1}^{+}$or Iba- $\mathrm{l}^{+}$microglia proliferate in the perilesional regions and accumulate in the injury core during the first week after injury before the astrocytic barrier is formed $(88,90)$. Interestingly, the depletion of this reactive microglia leads to a disorganized astrocytic wall, exacerbated inflammation, and increased neuronal death $(12,91)$, suggesting that microglial response effectively delineates the injured territory and guides the organization of astrocytes around the lesion. Overall, the overwhelming experimental evidence outlines the importance of astrocytes and microglia crosstalk in modulating the spatial properties of the glial scar following ischemia.

\section{ASTROGLIOSIS AND GLIAL SCARRING}

Astrocyte reactivity or astrogliosis takes place in all stroke phases $(6,92)$ and is featured by the upregulation of glial fibrillary acid protein (GFAP) (Figure 1) and the abundant secretion of inflammatory and fibrotic scar-forming mediators, 
including chondroitin sulfate proteoglycans (CSPGs) and TnC $(93,94)$ (Figure 4). During the tissue repair phase after cerebral ischemia, microglia-derived cytokines prime local astrocyte proliferation (12) or in neurogenic niches depending on the distance to the infarcted area (95). Proliferating astrocytes migrate to the injury core displaying distinct organization patterns $(96,97)$ (Figure 1$)$. In particular, astrocytes derived from radial glial progenitors cells (RGPCs) exhibit a strong astrogliosis profile with profound morphological alterations and form a highly dense barrier separating the infarcted and healthy tissue (11) (Figure 1). On the other hand, slow proliferating/ $\mathrm{NOTCHI}^{+}$astrocytes display mild astrogliosis profile and are recruited to the scar border, extending their processes towards the injury. Finally, a third group of non-proliferating astrocytes located in perilesional regions exhibit moderate astrogliosis features $(95,98)$.

The activation and organization of astrocytes at the glial scar involve distinct signaling pathways. For instance, it has been reported that STAT3 regulates several astrogliosis mechanisms, including astrocyte migration, GFAP expression, and cell hypertrophy. Consequently, deletion of STAT3 in astrocytes is translated into disrupted glial scar formation, accompanied by enhanced neuroinflammation and behavioral deficits $(99,100)$. Likewise, STAT3-mediated inhibition of RhoA is associated with proper astrocyte migration and adhesion at the scar (101). Evidence from in vitro experiments also suggests that this signaling pathway is implicated in PDGFR $\beta^{+}$cells and astrocyte communication, as the pericyte-conditioned medium after PDGFB treatment promotes astrocyte proliferation and astrocyte-mediated OPC differentiation via STAT3 (42). Remarkably, additional evidence indicates that thrombospondin (THBS) 4 expression induced by cerebral ischemia prompts the transcription of the nuclear factor I A (NFIA) in subventricular zone (SVZ) stem cells to promote astrogenesis. Therefore, THBS4deficient mice exhibit astrocyte deficiency and inappropriate scar formation (102). Remarkably, astrocyte reactivity following ischemia is also associated with endothelin-1 (ET-1)-meadited deposition of amyloid- $\beta$ (A $\beta$ ) (103). Accretion of this protein is linked to diminished $A \beta$ clearance by glial RAGE receptors and the progress of long-term cognitive deficits (104).

Of particular interest in the context of cerebral ischemia is TGF- $\beta$ signaling. TGF- $\beta$ is a multifunctional cytokine secreted by glia, pericytes, and endothelial cells, that is implicated in numerous processes during brain injury and remodeling, including regulation of astrogliosis and fibrosis (105) (Figure 3). Specifically, findings from cerebral ischemia models indicate that TGF- $\beta 1$ stimulation via ALK5 receptor or the intermediate-conductance calcium-activated potassium channel (KCa3.1) is required for GFAP upregulation, cell hypertrophy, and astrocyte arrangement at the scar, as well as CSPGs deposition $(106,107)$. Likewise, it has been reported that fibrinogen entering the parenchyma through the disrupted BBB stimulates astrogliosis via TGF- $\beta / S M A D$ signaling pathway. Genetic or pharmacological inhibition of fibrinogen diminishes astrocyte activation and deposition of fibrotic scar-forming molecules like neurocan (108). Additionally, TGF- $\beta 1$ or SMAD2/3 signaling has also been associated with the deposition of TnC, phosphacan, chondroitin synthase (ChSy)-1, 4-sulfated chondroitin-4-sulfotransferase-1 (C4st1) at the injury core $(109,110)$.

The dynamics of fibrotic proteins turnover remain elusive. Human samples from injured spinal cord indicate that phosphacan is upregulated at the scar border, while neurocan and versican are in the injury core (111). Interestingly, the 


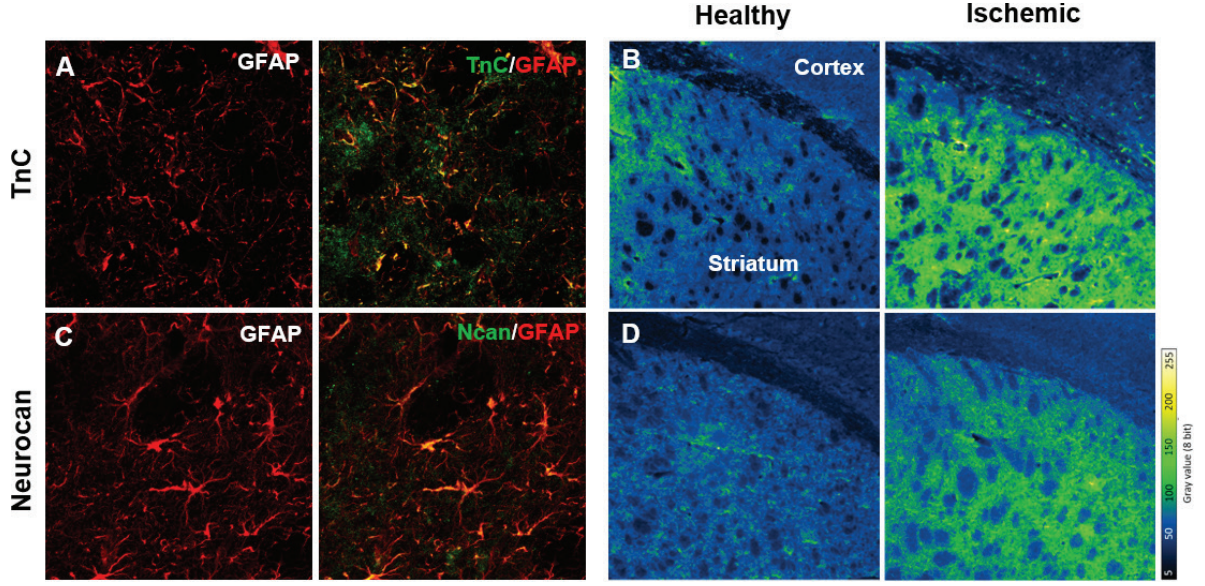

Figure 4. Tenascin-C and neurocan deposition at the fibrotic scar. A-B, $\mathrm{TnC}$ is one of the main ECM proteins deposited by reactive astrocytes after cerebral ischemia. Following injury, TnC is prominently upregulated in the injury core (striatum) and is degraded by MMPs ( $\mathrm{A}, \times 63$; $B, \times 10)$. C-D, Neurocan is a CSPG secreted by astrocytes at the injury core, which tightly interacts with $\mathrm{TnC}$ and acts as an inhibitory cue for cell reorganization in specific contexts $(\mathrm{C}, \times 63 ; \mathrm{D}, \times 10)$.

evidence suggests that CSPGs are differentially expressed and degraded upon injury (112), as neurocan, brevican, and versican are upregulated at the lesion core shortly after SCI, while phosphacan immunoreactivity appears two months after the lesion. Similarly, brevican expression persisted for two months in contrast to neurocan and versican that lasted for 30 days (111). In line with these observations, increased neurocan and phosphacan expression in GFAP ${ }^{+}$reactive astrocytes was reported after one month at the injured area in a cortical injury model (113) (Figure 4).

The role of $\mathrm{TnC}$ is particularly relevant in injury settings. TnC is abundantly secreted by reactive astrocytes $(114,115)$ dependently upon extracellular signalregulated kinases (ERK) and mitogen-activated protein kinase (MAPK) pathways (116) (Figure 4). Following ischemia, TnC remains in the lesion core during the first two weeks after injury (88) (Figure 4), and it is subsequently degraded by matrix metalloproteinases (MMPs), namely MMP2/9 (117). TnC possesses a multicellular domain that provides an ample ligand capacity, thus enabling the synthesis of other ECM proteins (118) and controlling how long these proteins will be retained at the fibrotic scar (119). TnC interacts with ICAM1, fibronectin, and perineural nets (PNNs) components (120), or glial and leukocyte integrins, such as $\alpha 9 \beta 1, \alpha \mathrm{V} \beta 3, \alpha 8 \beta 1$, and $\alpha \mathrm{V} \beta 6$, as well as the collagen receptor $\alpha 2 \beta$ (118) (Figure 3). For instance, it has been reported that $\mathrm{TnC}$-deficient mice exhibit fibronectin insufficiency following SCI or that TnC interaction with $\alpha 9 \beta 1$ and $\alpha \mathrm{V} \beta 3$ integrins control the fate and proliferation of cultured astrocytes or hematopoietic stem and progenitor cells (HSPCs) (118, 121).

Furthermore, it has been also demonstrated that TnC exerts immunoregulatory roles following injury. Findings from cerebral ischemia suggest that astrocyte-derived TnC binds to glial and leukocyte TLR4 and RAGE to regulate 
microglial activation and immune cell infiltration in association with ICAMI expression (88). Likewise, TnC-deficient mice experience increased lymphocyte and neutrophil infiltration following SCI (122), and TnC-shRNA treatment reduces the production of inflammatory mediators (123). The previous implies that $\mathrm{TnC}$ is a signaling substrate for recruiting scar-forming cells and modulate their activation state.

Finally, it is important to note that reactive astrocytes do not solely promote pathophysiological cascades leading to tissue scarring, but also control neuronal excitotoxicity via the excitatory amino acid transporter (EAAT1/2) glutamate transporters (124) and are major sources of neurotrophic factors $(125,126)$, including brain-derived neurotrophic factor (BDNF), glial cell line-derived neurotrophic factor (GDNF), and nerve growth factor (NGF) $(94,127)$, that promote chronic brain remodeling (Figure 2).

\section{MODULATION OF TISSUE SCARRING TO ENHANCE NEUROLOGICAL RECOVERY}

The downsides and benefits of glial/fibrotic scar for structural brain remodeling and neurological recovery have been widely discussed during the last two decades (128). A long-standing hypothesis postulates that glial and fibrotic scars act as physical and molecular inhibitory cues for cellular reorganization following injury $(106,129,130)$. In particular, it has been shown that increased CSPGs and TnC expression are correlated with diminished axonal rewiring $(122,131)$ and that ECM degradation by treatments like chondroitinase $A B C$ improves neurological recovery by facilitating the regeneration of neurites after SCI $(132,133)$. In the same way, it has been reported that experimental inhibition of pericyte-derived scarring enhances neurological recovery by preserving tight junctions and reducing vascular leakage (44), and promoting axonal growth (134).

Nonetheless, recent evidence is suggesting that the excessive experimental attenuation of tissue scarring diminishes functional recovery $(131,135)$. For instance, it has been demonstrated that glial/fibrotic scarring exerts neuroprotective roles by limiting the spread of inflammatory mediators into the intact tissue (136-138) and favoring tissue reorganization by ameliorating debris removal and activation of plasticity-related factors such as FGF and $\operatorname{BDNF}(139,140)$. Notably, a study by Anderson et al. (141) in a model of SCI strongly implies that the glial scar aids, rather than prevents, tissue reorganization after CNS lesion. Indeed, depending on the context, scar-forming proteins like TnC and CSPGs may exert inhibitory effects (142) or behave plasticity substrates (109, 140, 143). Alternatively, approaches depleting key mediators of astrocyte reactivity such as GFAP, vimentin, and Yap exacerbated infarct size, neuroinflammation, ECM deposition, and diminished neurological recovery $(131,135,144)$. Interestingly, ablation of reactive astrocytes at the glial scar also impairs revascularization (145), which is required for proper metabolic sustenance of newly proliferated neurons and glia repopulating the lesioned site. 
The previous reports entail that the effects of glial/fibrotic scars must be evaluated by considering the disease models and context (146). While the cellular and molecular remodeling governing scarring at the injury site in the early phases could be beneficial by limiting neuroinflammation and excitotoxicity, degradation of ECM deposits in the chromic phase enables tissue plasticity. The promotion of neuroprotective astrocyte phenotypes through the use of biomaterials (147) or direct astrocyte reprogramming $(148,149)$, as well as the functional reprogramming of PDGFR $\beta$ + mural cells $(150,151)$ may be promising strategies to enhance matrix degradation or neuronal repopulation in chronic stages post-ischemia to favor the formation of new functional cell networks.

\section{CONCLUSION}

Tissue scarring is one of the primary pathobiological processes that determine structural and functional reorganization of the injured CNS. It involves a tightly regulated spatiotemporal and multicompartmentalized reactivity of diverse cells that compose the NVU, including asrocytes, microglia, and mural PDGFR $\beta+$ cells that comprise pericytes. The crosstalk between the different cellular and molecular elements within the scar exerts essential immunoregulatory functions that aim at limiting the infiltration of inflammatory cells and mediators into the healthy tissues. In this context, scar-forming cells communicate through cytokines and ECM proteins to promote proliferation, differentiation, and migration of cells to the lesion core, and ultimately orchestrate an orderly cellular and molecular barrier that will be the basis for reorganization and replacement of the injured tissue. Neurological recovery after cerebral ischemia is strongly linked to the molecular properties of the central fibrotic scar, which determines to a large extent the inhibitory or promoting effects on neuronal plasticity. Because complete suppression of glial or fibrotic scar formation has been shown to have adverse effects, approaches seeking a time and context-dependent regulation of tissue scarring appear more promising, including strategies aiming to reprogram the functions of scar-forming cells.

Acknowledgment:This work was supported by grants from the Natural Sciences and Engineering Research Council of Canada (NSERC) (\#RGPIN-2017-06119), and the Fonds de recherche du Québec - Santé (FRQS) (\#35170) (all to AEA). AEA holds CIHR Tier 2 Canada Research Chair in molecular and cellular neurovascular interactions.

Conflict of Interest: The authors declare no potential conflicts of interest concerning research, authorship and/or publication of this manuscript.

Copyright and Permission Statement: The authors confirm that the materials included in this chapter do not violate copyright laws. Where relevant, appropriate permissions have been obtained from the original copyright holder(s), and all original sources have been appropriately acknowledged or referenced. 


\section{REFERENCES}

1. Hortega PR, de Estudios e Investigaciones Cientficas J para la A, Penfield W. Cerebral Cicatrix: The Reaction of Neuroglia and Microglia to Brain Wounds. Johns Hopkins Hospital; 1927.

2. Pekny M, Pekna M. Reactive gliosis in the pathogenesis of CNS diseases. Biochim Biophys Acta. 2016;1862(3):483-491. https://doi.org/10.1016/j.bbadis.2015.11.014

3. Karve IP, Taylor JM, Crack PJ. The contribution of astrocytes and microglia to traumatic brain injury. Br J Pharmacol. 2016;173(4):692-702. https://doi.org/10.1111/bph.13125

4. Bradbury EJ, Burnside ER. Moving beyond the glial scar for spinal cord repair. Nat Commun. 2019;10(1):3879. https://doi.org/10.1038/s41467-019-11707-7

5. Magaki SD, Williams CK, Vinters HV. Glial function (and dysfunction) in the normal \& ischemic brain. Neuropharmacology. 2018;134(Pt B):218-225. https://doi.org/10.1016/j.neuropharm. 2017.11.009

6. Burda JE, Sofroniew MV. Reactive gliosis and the multicellular response to CNS damage and disease. Neuron. 2014;81(2):229-248. https://doi.org/10.1016/j.neuron.2013.12.034

7. Sommer CJ. Ischemic stroke: experimental models and reality. Acta Neuropathol. 2017;133(2): 245-261. https://doi.org/10.1007/s00401-017-1667-0

8. Orr MB, Gensel JC. Spinal cord injury scarring and inflammation: therapies targeting glial and inflammatory responses. Neurotherapeutics. 2018;15(3):541-553. https://doi.org/10.1007/s13311 $-018-0631-6$

9. Dias DO, Kim H, Holl D, Werne Solnestam B, Lundeberg J, Carlén M, et al. Reducing Pericyte-Derived Scarring Promotes Recovery after Spinal Cord Injury. Cell. 2018;173(1):153-165.e22. https://doi. org/10.1016/j.cell.2018.02.004

10. Hackett AR, Lee JK. Understanding the NG2 Glial Scar after Spinal Cord Injury. Front Neurol. 2016;7:199. https://doi.org/10.3389/fneur.2016.00199

11. Wanner IB, Anderson MA, Song B, Levine J, Fernandez A, Gray-Thompson Z, et al. Glial scar borders are formed by newly proliferated, elongated astrocytes that interact to corral inflammatory and fibrotic cells via STAT3-dependent mechanisms after spinal cord injury. J Neurosci. 2013;33(31): 12870-12886. https://doi.org/10.1523/JNEUROSCI.2121-13.2013

12. Bellver-Landete V, Bretheau F, Mailhot B, Vallières N, Lessard M, Janelle M-E, et al. Microglia are an essential component of the neuroprotective scar that forms after spinal cord injury. Nat Commun. 2019;10(1):518. https://doi.org/10.1038/s41467-019-08446-0

13. Kjell J, Götz M. Filling the Gaps - A Call for Comprehensive Analysis of Extracellular Matrix of the Glial Scar in Region- and Injury-Specific Contexts. Front Cell Neurosci. 2020;14:32. https://doi. org/10.3389/fncel.2020.00032

14. Dzyubenko E, Manrique-Castano D, Kleinschnitz C, Faissner A, Hermann DM. Role of immune responses for extracellular matrix remodeling in the ischemic brain. Ther Adv Neurol Disord. 2018;11:1756286418818092. https://doi.org/10.1177/1756286418818092

15. Bonnans C, Chou J, Werb Z. Remodelling the extracellular matrix in development and disease. Nat Rev Mol Cell Biol. 2014;15(12):786-801. https://doi.org/10.1038/nrm3904

16. Grade S, Weng YC, Snapyan M, Kriz J, Malva JO, Saghatelyan A. Brain-derived neurotrophic factor promotes vasculature-associated migration of neuronal precursors toward the ischemic striatum. PLoS One. 2013;8(1):e55039. https://doi.org/10.1371/journal.pone.0055039

17. Hesp ZC, Yoseph RY, Suzuki R, Jukkola P, Wilson C, Nishiyama A, et al. Proliferating NG2-CellDependent Angiogenesis and Scar Formation Alter Axon Growth and Functional Recovery After Spinal Cord Injury in Mice. J Neurosci. 2018;38(6):1366-1382. https://doi.org/10.1523/ JNEUROSCI.3953-16.2017

18. Riew T-R, Choi J-H, Kim HL, Jin X, Lee M-Y. PDGFR- $\beta$-Positive Perivascular Adventitial Cells Expressing Nestin Contribute to Fibrotic Scar Formation in the Striatum of 3-NP Intoxicated Rats. Front Mol Neurosci. 2018;11:402. https://doi.org/10.3389/fnmol.2018.00402

19. Dias DO, Kalkitsas J, Kelahmetoglu Y, Estrada CP, Tatarishvili J, Ernst A, et al. Pericyte-derived fibrotic scarring is conserved across diverse central nervous system lesions. BioRxiv. 2020 May 2; https://doi. org/10.1101/2020.04.30.068965 
20. Luo X, Yang S, Liang J, Zhai Y, Shen M, Sun J, et al. Choroidal pericytes promote subretinal fibrosis after experimental photocoagulation. Dis Model Mech. 2018;11(4). https://doi.org/10.1242/ dmm.032060

21. Olson JK, Miller SD. Microglia initiate central nervous system innate and adaptive immune responses through multiple TLRs. J Immunol. 2004;173(6):3916-3924. https://doi.org/10.4049/ jimmunol.173.6.3916

22. Stark K, Eckart A, Haidari S, Tirniceriu A, Lorenz M, von Brühl M-L, et al. Capillary and arteriolar pericytes attract innate leukocytes exiting through venules and "instruct" them with pattern-recognition and motility programs. Nat Immunol. 2013;14(1):41-51. https://doi.org/10.1038/ni.2477

23. Rustenhoven J, Jansson D, Smyth LC, Dragunow M. Brain pericytes as mediators of neuroinflammation. Trends Pharmacol Sci. 2017;38(3):291-304. https://doi.org/10.1016/j.tips.2016.12.001

24. Stebbins MJ, Gastfriend BD, Canfield SG, Lee M-S, Richards D, Faubion MG, et al. Human pluripotent stem cell-derived brain pericyte-like cells induce blood-brain barrier properties. Sci Adv. 2019;5(3):eaau7375. https://doi.org/10.1126/sciadv.aau7375

25. Armulik A, Genové G, Mäe M, Nisancioglu MH, Wallgard E, Niaudet C, et al. Pericytes regulate the blood-brain barrier. Nature. 2010;468(7323):557-561. https://doi.org/10.1038/nature09522

26. Leaf IA, Nakagawa S, Johnson BG, Cha JJ, Mittelsteadt K, Guckian KM, et al. Pericyte MyD88 and IRAK4 control inflammatory and fibrotic responses to tissue injury. J Clin Invest. 2017 Jan 3; https:// doi.org/10.1172/JCI87532

27. Guijarro-Muñoz I, Compte M, Álvarez-Cienfuegos A, Álvarez-Vallina L, Sanz L. Lipopolysaccharide activates Toll-like receptor 4 (TLR4)-mediated NF-kB signaling pathway and pro-inflammatory response in human pericytes. J Biol Chem. 2014;289(4):2457-2468. https://doi.org/10.1074/jbc. M113.521161

28. Komuta Y, Teng X, Yanagisawa H, Sango K, Kawamura K, Kawano H. Expression of transforming growth factor-beta receptors in meningeal fibroblasts of the injured mouse brain. Cell Mol Neurobiol. 2010;30(1):101-111. https://doi.org/10.1007/s10571-009-9435-x

29. Minutti CM, Modak RV, Macdonald F, Li F, Smyth DJ, Dorward DA, et al. A Macrophage-Pericyte Axis Directs Tissue Restoration via Amphiregulin-Induced Transforming Growth Factor Beta Activation. Immunity. 2019;50(3):645-654.e6. https://doi.org/10.1016/j.immuni.2019.01.008

30. Kovac A, Erickson MA, Banks WA. Brain microvascular pericytes are immunoactive in culture: cytokine, chemokine, nitric oxide, and LRP-1 expression in response to lipopolysaccharide. J Neuroinflammation. 2011;8:139. https://doi.org/10.1186/1742-2094-8-139

31. Matsumoto J, Takata F, Machida T, Takahashi H, Soejima Y, Funakoshi M, et al. Tumor necrosis factor- $\alpha$-stimulated brain pericytes possess a unique cytokine and chemokine release profile and enhance microglial activation. Neurosci Lett. 2014;578:133-138. https://doi.org/10.1016/j. neulet.2014.06.052

32. Tigges U, Boroujerdi A, Welser-Alves JV, Milner R. TNF- $\alpha$ promotes cerebral pericyte remodeling in vitro, via a switch from $\alpha 1$ to $\alpha 2$ integrins. J Neuroinflammation. 2013;10:33. https://doi. org/10.1186/1742-2094-10-33

33. Duan L, Zhang X-D, Miao W-Y, Sun Y-J, Xiong G, Wu Q, et al. PDGFr $\beta$ Cells Rapidly Relay Inflammatory Signal from the Circulatory System to Neurons via Chemokine CCL2. Neuron. 2018;100(1):183-200.e8. https://doi.org/10.1016/j.neuron.2018.08.030

34. Hinojosa AE, Garcia-Bueno B, Leza JC, Madrigal JLM. CCL2/MCP-1 modulation of microglial activation and proliferation. J Neuroinflammation. 2011;8:77. https://doi.org/10.1186/1742-2094-8-77

35. Popichak KA, Afzali MF, Kirkley KS, Tjalkens RB. Glial-neuronal signaling mechanisms underlying the neuroinflammatory effects of manganese. J Neuroinflammation. 2018;15(1):324. https://doi. org/10.1186/s12974-018-1349-4

36. Li B, Bedard K, Sorce S, Hinz B, Dubois-Dauphin M, Krause K-H. NOX4 expression in human microglia leads to constitutive generation of reactive oxygen species and to constitutive IL-6 expression. J Innate Immun. 2009;1(6):570-581. https://doi.org/10.1159/000235563

37. Zehendner CM, Sebastiani A, Hugonnet A, Bischoff F, Luhmann HJ, Thal SC. Traumatic brain injury results in rapid pericyte loss followed by reactive pericytosis in the cerebral cortex. Sci Rep. 2015;5:13497. https://doi.org/10.1038/srep13497 
38. Dore-Duffy P, Owen C, Balabanov R, Murphy S, Beaumont T, Rafols JA. Pericyte migration from the vascular wall in response to traumatic brain injury. Microvasc Res. 2000;60(1):55-69. https://doi. org/10.1006/mvre.2000.2244

39. Duz B, Oztas E, Erginay T, Erdogan E, Gonul E. The effect of moderate hypothermia in acute ischemic stroke on pericyte migration: an ultrastructural study. Cryobiology. 2007;55(3):279-284. https://doi. org/10.1016/j.cryobiol.2007.08.009

40. Shibahara T, Ago T, Nakamura K, Tachibana M, Yoshikawa Y, Komori M, et al. Pericyte-Mediated Tissue Repair through PDGFR $\beta$ Promotes Peri-Infarct Astrogliosis, Oligodendrogenesis, and Functional Recovery after Acute Ischemic Stroke. Eneuro. 2020;7(2). https://doi.org/10.1523/ ENEURO.0474-19.2020

41. Shen J, Ishii Y, Xu G, Dang TC, Hamashima T, Matsushima T, et al. PDGFR- $\beta$ as a positive regulator of tissue repair in a mouse model of focal cerebral ischemia. J Cereb Blood Flow Metab. 2012;32(2): 353-367. https://doi.org/10.1038/jcbfm.2011.136

42. Makihara N, Arimura K, Ago T, Tachibana M, Nishimura A, Nakamura K, et al. Involvement of platelet-derived growth factor receptor $\beta$ in fibrosis through extracellular matrix protein production after ischemic stroke. Exp Neurol. 2015;264:127-134. https://doi.org/10.1016/j.expneurol.2014.12.007

43. Roth M, Gaceb A, Enström A, Padel T, Genové G, Özen I, et al. Regulator of G-protein signaling 5 regulates the shift from perivascular to parenchymal pericytes in the chronic phase after stroke. FASEB J. 2019;33(8):8990-8998. https://doi.org/10.1096/fj.201900153R

44. Özen I, Roth M, Barbariga M, Gaceb A, Deierborg T, Genové G, et al. Loss of Regulator of G-Protein Signaling 5 Leads to Neurovascular Protection in Stroke. Stroke. 2018;49(9):2182-2190. https://doi. org/10.1161/STROKEAHA.118.020124

45. Soderblom C, Luo X, Blumenthal E, Bray E, Lyapichev K, Ramos J, et al. Perivascular fibroblasts form the fibrotic scar after contusive spinal cord injury. J Neurosci. 2013;33(34):13882-13887. https://doi. org/10.1523/JNEUROSCI.2524-13.2013

46. Zhu Y, Soderblom C, Trojanowsky M, Lee D-H, Lee JK. Fibronectin Matrix Assembly after Spinal Cord Injury. J Neurotrauma. 2015;32(15):1158-1167. https://doi.org/10.1089/neu.2014.3703

47. Yamagami T, Pleasure DE, Lam KS, Zhou CJ. Transient activation of Wnt/ß-catenin signaling reporter in fibrotic scar formation after compression spinal cord injury in adult mice. Biochem Biophys Res Commun. 2018;496(4):1302-1307. https://doi.org/10.1016/j.bbrc.2018.02.004

48. Göritz C, Dias DO, Tomilin N, Barbacid M, Shupliakov O, Frisén J. A pericyte origin of spinal cord scar tissue. Science. 2011;333(6039):238-242. https://doi.org/10.1126/science.1203165

49. Ignotz RA, Massagué J. Transforming growth factor-beta stimulates the expression of fibronectin and collagen and their incorporation into the extracellular matrix. J Biol Chem. 1986;261(9):4337-4345. https://doi.org/10.1016/S0021-9258(17)35666-1

50. Zhang Y, Yang X. The Roles of TGF- $\beta$ Signaling in Cerebrovascular Diseases. Front Cell Dev Biol. 2020 Sep 18;8:567682. https://doi.org/10.3389/fcell.2020.567682

51. Moshayedi P, Ng G, Kwok JCF, Yeo GSH, Bryant CE, Fawcett JW, et al. The relationship between glial cell mechanosensitivity and foreign body reactions in the central nervous system. Biomaterials. 2014;35(13):3919-3925. https://doi.org/10.1016/j.biomaterials.2014.01.038

52. Moeendarbary E, Weber IP, Sheridan GK, Koser DE, Soleman S, Haenzi B, et al. The soft mechanical signature of glial scars in the central nervous system. Nat Commun. 2017;8:14787. https://doi. org/10.1038/ncomms 14787

53. Swift J, Ivanovska IL, Buxboim A, Harada T, Dingal PCDP, Pinter J, et al. Nuclear lamin-A scales with tissue stiffness and enhances matrix-directed differentiation. Science. 2013;341(6149):1240104. https://doi.org/10.1126/science.1240104

54. Koch D, Rosoff WJ, Jiang J, Geller HM, Urbach JS. Strength in the periphery: growth cone biomechanics and substrate rigidity response in peripheral and central nervous system neurons. Biophys J. 2012;102(3):452-460. https://doi.org/10.1016/j.bpj.2011.12.025

55. Jiang FX, Yurke B, Firestein BL, Langrana NA. Neurite outgrowth on a DNA crosslinked hydrogel with tunable stiffnesses. Ann Biomed Eng. 2008;36(9):1565-1579. https://doi.org/10.1007/ sl0439-008-9530-z 
56. Thored P, Wood J, Arvidsson A, Cammenga J, Kokaia Z, Lindvall O. Long-term neuroblast migration along blood vessels in an area with transient angiogenesis and increased vascularization after stroke. Stroke. 2007;38(11):3032-3039. https://doi.org/10.1161/STROKEAHA.107.488445

57. Bonkowski D, Katyshev V, Balabanov RD, Borisov A, Dore-Duffy P. The CNS microvascular pericyte: pericyte-astrocyte crosstalk in the regulation of tissue survival. Fluids Barriers CNS. 2011;8(1):8. https://doi.org/10.1186/2045-8118-8-8

58. Winkler EA, Bell RD, Zlokovic BV. Central nervous system pericytes in health and disease. Nat Neurosci. 2011;14(11):1398-1405. https://doi.org/10.1038/nn.2946

59. Perrot CY, Herrera JL, Fournier-Goss AE, Komatsu M. Prostaglandin E2 breaks down pericyteendothelial cell interaction via EP1 and EP4-dependent downregulation of pericyte N-cadherin, connexin-43, and R-Ras. Sci Rep. 2020;10(1):11186. https://doi.org/10.1038/s41598-020-68019-w

60. Liu Q, Liang X, Wang Q, Wilson EN, Lam R, Wang J, et al. PGE2 signaling via the neuronal EP2 receptor increases injury in a model of cerebral ischemia. Proc Natl Acad Sci USA. 2019;116(20):10019_ 10024. https://doi.org/10.1073/pnas.1818544116

61. Beltramo E, Pomero F, Allione A, D’Alù F, Ponte E, Porta M. Pericyte adhesion is impaired on extracellular matrix produced by endothelial cells in high hexose concentrations. Diabetologia. 2002;45(3):416-419. https://doi.org/10.1007/s00125-001-0761-x

62. Rafalski VA, Merlini M, Akassoglou K. Pericytes: the brain's very first responders? Neuron. 2018;100(1):11-13. https://doi.org/10.1016/j.neuron.2018.09.033

63. Guruswamy R, ElAli A. Complex roles of microglial cells in ischemic stroke pathobiology: new insights and future directions. Int J Mol Sci. 2017;18(3). https://doi.org/10.3390/ijms18030496

64. Lou N, Takano T, Pei Y, Xavier AL, Goldman SA, Nedergaard M. Purinergic receptor P2RY12dependent microglial closure of the injured blood-brain barrier. Proc Natl Acad Sci USA. 2016;113(4): 1074-1079. https://doi.org/10.1073/pnas.1520398113

65. Eyo UB, Peng J, Swiatkowski P, Mukherjee A, Bispo A, Wu L-J. Neuronal hyperactivity recruits microglial processes via neuronal NMDA receptors and microglial P2Y12 receptors after status epilepticus. J Neurosci. 2014;34(32):10528-10540. https://doi.org/10.1523/JNEUROSCI.0416-14.2014

66. Origlia N, Criscuolo C, Arancio O, Yan SS, Domenici L. RAGE inhibition in microglia prevents ischemia-dependent synaptic dysfunction in an amyloid-enriched environment. J Neurosci. 2014;34(26):8749-8760. https://doi.org/10.1523/JNEUROSCI.0141-14.2014

67. Muhammad S, Barakat W, Stoyanov S, Murikinati S, Yang H, Tracey KJ, et al. The HMGBl receptor RAGE mediates ischemic brain damage. J Neurosci. 2008;28(46):12023-12031. https://doi. org/10.1523/JNEUROSCI.2435-08.2008

68. Fernández-Arjona MDM, Grondona JM, Granados-Durán P, Fernández-Llebrez P, López-Ávalos MD. Microglia morphological categorization in a rat model of neuroinflammation by hierarchical cluster and principal components analysis. Front Cell Neurosci. 2017;11:235. https://doi.org/10.3389/ fncel.2017.00235

69. Buscemi L, Price M, Bezzi P, Hirt L. Spatio-temporal overview of neuroinflammation in an experimental mouse stroke model. Sci Rep. 2019;9(1):507. https://doi.org/10.1038/s41598-018-36598-4

70. Perego C, Fumagalli S, De Simoni M-G. Temporal pattern of expression and colocalization of microglia/macrophage phenotype markers following brain ischemic injury in mice. J Neuroinflammation. 2011;8:174. https://doi.org/10.1186/1742-2094-8-174

71. Stence N, Waite M, Dailey ME. Dynamics of microglial activation: a confocal time-lapse analysis in hippocampal slices. Glia. 2001;33(3):256-266. https://doi.org/10.1002/1098-1136(200103)33: 3<256::AID-GLIA1024>3.0.CO;2-J

72. Gao H-M, Zhou H, Zhang F, Wilson BC, Kam W, Hong J-S. HMGBl acts on microglia Macl to mediate chronic neuroinflammation that drives progressive neurodegeneration. J Neurosci. 2011;31(3):10811092. https://doi.org/10.1523/JNEUROSCI.3732-10.2011

73. Hersh J, Yang S-H. Glia-immune interactions post-ischemic stroke and potential therapies. Exp Biol Med. 2018;243(17-18):1302-1312. https://doi.org/10.1177/1535370218818172

74. Heindl S, Gesierich B, Benakis C, Llovera G, Duering M, Liesz A. Automated morphological analysis of microglia after stroke. Front Cell Neurosci. 2018;12:106. https://doi.org/10.3389/fncel.2018.00106 
75. Davis BM, Salinas-Navarro M, Cordeiro MF, Moons L, De Groef L. Characterizing microglia activation: a spatial statistics approach to maximize information extraction. Sci Rep. 2017;7(1):1576. https://doi. org/10.1038/s41598-017-01747-8

76. Qin C, Zhou L-Q, Ma X-T, Hu Z-W, Yang S, Chen M, et al. Dual functions of microglia in ischemic stroke. Neurosci Bull. 2019;35(5):921-933. https://doi.org/10.1007/s12264-019-00388-3

77. Parakalan R, Jiang B, Nimmi B, Janani M, Jayapal M, Lu J, et al. Transcriptome analysis of amoeboid and ramified microglia isolated from the corpus callosum of rat brain. BMC Neurosci. 2012;13:64. https://doi.org/10.1186/1471-2202-13-64

78. Lana D, Ugolini F, Wenk GL, Giovannini MG, Zecchi-Orlandini S, Nosi D. Microglial distribution, branching, and clearance activity in aged rat hippocampus are affected by astrocyte meshwork integrity: evidence of a novel cell-cell interglial interaction. FASEB J. 2019;33(3):4007-4020. https://doi. org/10.1096/fj.201801539R

79. Jha MK, Jo M, Kim J-H, Suk K. Microglia-Astrocyte Crosstalk: An Intimate Molecular Conversation. Neuroscientist. 2019;25(3):227-240. https://doi.org/10.1177/1073858418783959

80. Liddelow SA, Guttenplan KA, Clarke LE, Bennett FC, Bohlen CJ, Schirmer L, et al. Neurotoxic reactive astrocytes are induced by activated microglia. Nature. 2017;541(7638):481-487. https://doi. org/10.1038/nature21029

81. Gao Z, Zhu Q, Zhang Y, Zhao Y, Cai L, Shields CB, et al. Reciprocal modulation between microglia and astrocyte in reactive gliosis following the CNS injury. Mol Neurobiol. 2013;48(3):690-701. https:// doi.org/10.1007/s12035-013-8460-4

82. Hyvärinen T, Hagman S, Ristola M, Sukki L, Veijula K, Kreutzer J, et al. Co-stimulation with IL-1 $\beta$ and TNF- $\alpha$ induces an inflammatory reactive astrocyte phenotype with neurosupportive characteristics in a human pluripotent stem cell model system. Sci Rep. 2019 Nov;9(1):16944. https://doi.org/10.1038/ s41598-019-53414-9

83. Hamby ME, Coppola G, Ao Y, Geschwind DH, Khakh BS, Sofroniew MV. Inflammatory mediators alter the astrocyte transcriptome and calcium signaling elicited by multiple G-protein-coupled receptors. J Neurosci. 2012;32(42):14489-14510. https://doi.org/10.1523/JNEUROSCI.1256-12.2012

84. Davalos D, Grutzendler J, Yang G, Kim JV, Zuo Y, Jung S, et al. ATP mediates rapid microglial response to local brain injury in vivo. Nat Neurosci. 2005;8(6):752-758. https://doi.org/10.1038/nnl472

85. Choi SS, Lee HJ, Lim I, Satoh J, Kim SU. Human astrocytes: secretome profiles of cytokines and chemokines. PLoS One. 2014;9(4):e92325. https://doi.org/10.1371/journal.pone.0092325

86. Yoshizaki S, Tamaru T, Hara M, Kijima K, Tanaka M, Konno D-J, et al. Microglial inflammation after chronic spinal cord injury is enhanced by reactive astrocytes via the fibronectin/ $\beta 1$ integrin pathway. J Neuroinflammation. 2021;18(1):12. https://doi.org/10.1186/s12974-020-02059-x

87. Rolls A, Shechter R, London A, Segev Y, Jacob-Hirsch J, Amariglio N, et al. Two faces of chondroitin sulfate proteoglycan in spinal cord repair: a role in microglia/macrophage activation. PLoS Med. 2008;5(8):e171. https://doi.org/10.1371/journal.pmed.0050171

88. Manrique-Castano D, Dzyubenko E, Borbor M, Vasileiadou P, Kleinschnitz C, Roll L, et al. Tenascin-C preserves microglia surveillance and restricts leukocyte and, more specifically, T cell infiltration of the ischemic brain. Brain Behav Immun. 2021;91:639-648. https://doi.org/10.1016/j.bbi.2020.10.016

89. Ramírez G, Toro R, Döbeli H, von Bernhardi R. Protection of rat primary hippocampal cultures from A beta cytotoxicity by pro-inflammatory molecules is mediated by astrocytes. Neurobiol Dis. 2005;19(1-2):243-254. https://doi.org/10.1016/j.nbd.2005.01.007

90. Li T, Pang S, Yu Y, Wu X, Guo J, Zhang S. Proliferation of parenchymal microglia is the main source of microgliosis after ischaemic stroke. Brain. 2013;136(Pt 12):3578-3588. https://doi.org/10.1093/ brain/awt 287

91. Feng Y, Liao S, Wei C, Jia D, Wood K, Liu Q, et al. Infiltration and persistence of lymphocytes during late-stage cerebral ischemia in middle cerebral artery occlusion and photothrombotic stroke models. J Neuroinflammation. 2017;14(1):248. https://doi.org/10.1186/s12974-017-1017-0

92. Pekny M, Pekna M. Astrocyte reactivity and reactive astrogliosis: costs and benefits. Physiol Rev. 2014;94(4):1077-1098. https://doi.org/10.1152/physrev.00041.2013

93. George N, Geller HM. Extracellular matrix and traumatic brain injury. J Neurosci Res. 2018;96(4): 573-588. https://doi.org/10.1002/jnr.24151 
94. Wiese S, Karus M, Faissner A. Astrocytes as a source for extracellular matrix molecules and cytokines. Front Pharmacol. 2012;3:120. https://doi.org/10.3389/fphar.2012.00120

95. Barreto GE, Sun X, Xu L, Giffard RG. Astrocyte proliferation following stroke in the mouse depends on distance from the infarct. PLoS One. 2011;6(11):e27881. https://doi.org/10.1371/journal. pone.0027881

96. Liao R, Jiang L, Wang R, Zhao H, Chen Y, Li Y, et al. Histidine provides long-term neuroprotection after cerebral ischemia through promoting astrocyte migration. Sci Rep. 2015;5:15356. https://doi. org/10.1038/srep15356

97. Suzuki T, Sakata H, Kato C, Connor JA, Morita M. Astrocyte activation and wound healing in intact-skull mouse after focal brain injury. Eur J Neurosci. 2012;36(12):3653-3664. https://doi. org/10.1111/j.1460-9568.2012.08280.x

98. Shimada IS, Borders A, Aronshtam A, Spees JL. Proliferating reactive astrocytes are regulated by Notch-1 in the peri-infarct area after stroke. Stroke. 2011;42(11):3231-3237. https://doi.org/10.1161/ STROKEAHA.111.623280

99. Okada S, Nakamura M, Katoh H, Miyao T, Shimazaki T, Ishii K, et al. Conditional ablation of Stat 3 or Socs3 discloses a dual role for reactive astrocytes after spinal cord injury. Nat Med. 2006;12(7):829834. https://doi.org/10.1038/nml425

100. Herrmann JE, Imura T, Song B, Qi J, Ao Y, Nguyen TK, et al. STAT3 is a critical regulator of astrogliosis and scar formation after spinal cord injury. J Neurosci. 2008;28(28):7231-7243. https://doi. org/10.1523/JNEUROSCI.1709-08.2008

101. Renault-Mihara F, Mukaino M, Shinozaki M, Kumamaru H, Kawase S, Baudoux M, et al. Regulation of RhoA by STAT3 coordinates glial scar formation. J Cell Biol. 2017;216(8):2533-2550. https://doi. org/10.1083/jcb.201610102

102. Benner EJ, Luciano D, Jo R, Abdi K, Paez-Gonzalez P, Sheng H, et al. Protective astrogenesis from the SVZ niche after injury is controlled by Notch modulator Thbs4. Nature. 2013;497(7449):369-373. https://doi.org/10.1038/nature12069

103. Hung VKL, Yeung PKK, Lai AKW, Ho MCY, Lo ACY, Chan KC, et al. Selective astrocytic endothelin-1 overexpression contributes to dementia associated with ischemic stroke by exaggerating astrocyte-derived amyloid secretion. J Cereb Blood Flow Metab. 2015;35(10):1687-1696. https://doi. org/10.1038/jcbfm.2015.109

104. Min L-J, Iwanami J, Shudou M, Bai H-Y, Shan B-S, Higaki A, et al. Deterioration of cognitive function after transient cerebral ischemia with amyloid- $\beta$ infusion-possible amelioration of cognitive function by AT2 receptor activation. J Neuroinflammation. 2020;17(1):106. https://doi.org/10.1186/ s12974-020-01775-8

105. Patel RK, Prasad N, Kuwar R, Haldar D, Abdul-Muneer PM. Transforming growth factor-beta 1 signaling regulates neuroinflammation and apoptosis in mild traumatic brain injury. Brain Behav Immun. 2017;64:244-258. https://doi.org/10.1016/j.bbi.2017.04.012

106. Zhang R, Wu Y, Xie F, Zhong Y, Wang Y, Xu M, et al. RGMa mediates reactive astrogliosis and glial scar formation through TGF $\beta 1 / S m a d 2 / 3$ signaling after stroke. Cell Death Differ. 2018;25(8):1503-1516. https://doi.org/10.1038/s41418-018-0058-y

107. Yu Z, Yu P, Chen H, Geller HM. Targeted inhibition of KCa3.1 attenuates TGF- $\beta$-induced reactive astrogliosis through the Smad2/3 signaling pathway. J Neurochem. 2014;130(1):41-49. https://doi. org/10.1111/jnc. 12710

108. Schachtrup C, Ryu JK, Helmrick MJ, Vagena E, Galanakis DK, Degen JL, et al. Fibrinogen triggers astrocyte scar formation by promoting the availability of active TGF-beta after vascular damage. J Neurosci. 2010;30(17):5843-5854. https://doi.org/10.1523/JNEUROSCI.0137-10.2010

109. Susarla BTS, Laing ED, Yu P, Katagiri Y, Geller HM, Symes AJ. Smad proteins differentially regulate transforming growth factor- $\beta$-mediated induction of chondroitin sulfate proteoglycans. J Neurochem. 2011;119(4):868-878. https://doi.org/10.1111/j.1471-4159.2011.07470.x

110. Smith GM, Hale JH. Macrophage/Microglia regulation of astrocytic tenascin: synergistic action of transforming growth factor-beta and basic fibroblast growth factor. J Neurosci. 1997;17(24): 9624-9633. https://doi.org/10.1523/JNEUROSCI.17-24-09624.1997 
111. Buss A, Pech K, Kakulas BA, Martin D, Schoenen J, Noth J, et al. NG2 and phosphacan are present in the astroglial scar after human traumatic spinal cord injury. BMC Neurol. 2009;9:32. https://doi. org/10.1186/1471-2377-9-32

112. Jones LL, Margolis RU, Tuszynski MH. The chondroitin sulfate proteoglycans neurocan, brevican, phosphacan, and versican are differentially regulated following spinal cord injury. Exp Neurol. 2003;182(2):399-411. https://doi.org/10.1016/S0014-4886(03)00087-6

113. McKeon RJ, Jurynec MJ, Buck CR. The chondroitin sulfate proteoglycans neurocan and phosphacan are expressed by reactive astrocytes in the chronic CNS glial scar. J Neurosci. 1999;19(24):1077810788. https://doi.org/10.1523/JNEUROSCI.19-24-10778.1999

114. Laywell ED, Dörries U, Bartsch U, Faissner A, Schachner M, Steindler DA. Enhanced expression of the developmentally regulated extracellular matrix molecule tenascin following adult brain injury. Proc Natl Acad Sci USA. 1992;89(7):2634-2638. https://doi.org/10.1073/pnas.89.7.2634

115. Roll L, Faissner A. Tenascins in CNS lesions. Semin Cell Dev Biol. 2019;89:118-124. https://doi. org/10.1016/j.semcdb.2018.09.012

116. Okada T, Suzuki H. The Role of Tenascin-C in Tissue Injury and Repair After Stroke. Front Immunol. 2020;11:607587. https://doi.org/10.3389/fimmu.2020.607587

117. Lu P, Takai K, Weaver VM, Werb Z. Extracellular matrix degradation and remodeling in development and disease. Cold Spring Harb Perspect Biol. 2011;3(12). https://doi.org/10.1101/cshperspect. a005058

118. Tucker RP, Chiquet-Ehrismann R. Tenascin-C: Its functions as an integrin ligand. Int J Biochem Cell Biol. 2015;65:165-168. https://doi.org/10.1016/j.biocel.2015.06.003

119. Marzeda AM, Midwood KS. Internal Affairs: Tenascin-C as a Clinically Relevant, Endogenous Driver of Innate Immunity. J Histochem Cytochem. 2018;66(4):289-304. https://doi.org/10.1369 /0022155418757443

120. Midwood KS, Orend G. The role of tenascin-C in tissue injury and tumorigenesis. J Cell Commun Signal. 2009;3(3-4):287-310. https://doi.org/10.1007/s12079-009-0075-1

121. Nishio T, Kawaguchi S, Iseda T, Kawasaki T, Hase T. Secretion of tenascin-C by cultured astrocytes: regulation of cell proliferation and process elongation. Brain Res. 2003;990(1-2):129-140. https:// doi.org/10.1016/S0006-8993(03)03448-6

122. Schreiber J, Schachner M, Schumacher U, Lorke DE. Extracellular matrix alterations, accelerated leukocyte infiltration and enhanced axonal sprouting after spinal cord hemisection in tenascin-Cdeficient mice. Acta Histochem. 2013;115(8):865-878. https://doi.org/10.1016/j.acthis.2013.04.009

123. Johnson K, Chelluboina B. E-089 Early transcriptional regulation of tenascin-c attenuates post-stroke brain damage. Electronic poster abstracts. BMA House, Tavistock Square, London, WC1H 9JR: BMJ Publishing Group Ltd.; 2019. p. A97.1-A97. https://doi.org/10.1136/neurintsurg-2019-SNIS.164

124. Bjørnsen LP, Hadera MG, Zhou Y, Danbolt NC, Sonnewald U. The GLT-1 (EAAT2; slcla2) glutamate transporter is essential for glutamate homeostasis in the neocortex of the mouse. J Neurochem. 2014;128(5):641-649. https://doi.org/10.1111/jnc.12509

125. Zamanian JL, Xu L, Foo LC, Nouri N, Zhou L, Giffard RG, et al. Genomic analysis of reactive astrogliosis. J Neurosci. 2012;32(18):6391-6410. https://doi.org/10.1523/JNEUROSCI.6221-11.2012

126. Hayakawa K, Esposito E, Wang X, Terasaki Y, Liu Y, Xing C, et al. Transfer of mitochondria from astrocytes to neurons after stroke. Nature. 2016;535(7613):551-555. https://doi.org/10.1038/nature18928

127. Zhang L, Zhang ZG, Chopp M. The neurovascular unit and combination treatment strategies for stroke. Trends Pharmacol Sci. 2012;33(8):415-422. https://doi.org/10.1016/j.tips.2012.04.006

128. Cregg JM, DePaul MA, Filous AR, Lang BT, Tran A, Silver J. Functional regeneration beyond the glial scar. Exp Neurol. 2014;253:197-207. https://doi.org/10.1016/j.expneurol.2013.12.024

129. Wilhelmsson U, Li L, Pekna M, Berthold C-H, Blom S, Eliasson C, et al. Absence of glial fibrillary acidic protein and vimentin prevents hypertrophy of astrocytic processes and improves post-traumatic regeneration. J Neurosci. 2004;24(21):5016-5021. https://doi.org/10.1523/JNEUROSCI.0820-04.2004

130. Silver J, Miller JH. Regeneration beyond the glial scar. Nat Rev Neurosci. 2004;5(2):146-156. https:// doi.org/10.1038/nrn1326

131. Liu Z, Li Y, Cui Y, Roberts C, Lu M, Wilhelmsson U, et al. Beneficial effects of gfap/vimentin reactive astrocytes for axonal remodeling and motor behavioral recovery in mice after stroke. Glia. 2014;62(12):2022-2033. https://doi.org/10.1002/glia.22723 
132. Bradbury EJ, Moon LDF, Popat RJ, King VR, Bennett GS, Patel PN, et al. Chondroitinase ABC promotes functional recovery after spinal cord injury. Nature. 2002;416(6881):636-640. https://doi. org/10.1038/416636a

133. Barritt AW, Davies M, Marchand F, Hartley R, Grist J, Yip P, et al. Chondroitinase ABC promotes sprouting of intact and injured spinal systems after spinal cord injury. J Neurosci. 2006;26(42):1085610867. https://doi.org/10.1523/JNEUROSCI.2980-06.2006

134. Ruschel J, Hellal F, Flynn KC, Dupraz S, Elliott DA, Tedeschi A, et al. Axonal regeneration. Systemic administration of epothilone B promotes axon regeneration after spinal cord injury. Science. 2015;348(6232):347-352. https://doi.org/10.1126/science.aaa2958

135. Brenner M. Role of GFAP in CNS injuries. Neurosci Lett. 2014;565:7-13. https://doi.org/10.1016/j. neulet.2014.01.055

136. Voskuhl RR, Peterson RS, Song B, Ao Y, Morales LBJ, Tiwari-Woodruff S, et al. Reactive astrocytes form scar-like perivascular barriers to leukocytes during adaptive immune inflammation of the CNS. J Neurosci. 2009;29(37):11511-11522. https://doi.org/10.1523/JNEUROSCI.1514-09.2009

137. Cekanaviciute E, Buckwalter MS. Astrocytes: integrative regulators of neuroinflammation in stroke and other neurological diseases. Neurotherapeutics. 2016;13(4):685-701. https://doi.org/10.1007/ s13311-016-0477-8

138. Kawano H, Kimura-Kuroda J, Komuta Y, Yoshioka N, Li HP, Kawamura K, et al. Role of the lesion scar in the response to damage and repair of the central nervous system. Cell Tissue Res. 2012;349(1):169_ 180. https://doi.org/10.1007/s00441-012-1336-5

139. Rolls A, Shechter R, Schwartz M. The bright side of the glial scar in CNS repair. Nat Rev Neurosci. 2009;10(3):235-241. https://doi.org/10.1038/nrn2591

140. Andrews MR, Czvitkovich S, Dassie E, Vogelaar CF, Faissner A, Blits B, et al. Alpha9 integrin promotes neurite outgrowth on tenascin- $C$ and enhances sensory axon regeneration. J Neurosci. 2009;29(17):5546-5557. https://doi.org/10.1523/JNEUROSCI.0759-09.2009

141. Anderson MA, Burda JE, Ren Y, Ao Y, O'Shea TM, Kawaguchi R, et al. Astrocyte scar formation aids central nervous system axon regeneration. Nature. 2016;532(7598):195-200. https://doi. org/10.1038/nature 17623

142. Faissner A, Kruse J. J1/tenascin is a repulsive substrate for central nervous system neurons. Neuron. 1990;5(5):627-637. https://doi.org/10.1016/0896-6273(90)90217-4

143. Siddiqui S, Horvat-Bröcker A, Faissner A. The glia-derived extracellular matrix glycoprotein tenascin-C promotes embryonic and postnatal retina axon outgrowth via the alternatively spliced fibronectin type III domain TNfnD. Neuron Glia Biol. 2008;4(4):271-283. https://doi.org/10.1017/ S1740925X09990020

144. Xie C, Shen X, Xu X, Liu H, Li F, Lu S, et al. Astrocytic YAP Promotes the Formation of Glia Scars and Neural Regeneration after Spinal Cord Injury. J Neurosci. 2020;40(13):2644-2662. https://doi. org/10.1523/JNEUROSCI.2229-19.2020

145. Williamson MR, Fuertes CJA, Dunn AK, Drew MR, Jones TA. Reactive astrocytes facilitate vascular repair and remodeling after stroke. Cell Rep. 2021;35(4):109048. https://doi.org/10.1016/j. celrep.2021.109048

146. Silver J. The glial scar is more than just astrocytes. Exp Neurol. 2016;286:147-149. https://doi. org/10.1016/j.expneurol.2016.06.018

147. Zuidema JM, Gilbert RJ, Gottipati MK. Biomaterial approaches to modulate reactive astroglial response. Cells Tissues Organs (Print). 2018;205(5-6):372-395. https://doi.org/10.1159/000494667

148. Yang T, Xing L, Yu W, Cai Y, Cui S, Chen G. Astrocytic reprogramming combined with rehabilitation strategy improves recovery from spinal cord injury. FASEB J. 2020;34(11):15504-15515. https://doi. org/10.1096/fj.202001657RR

149. Ma Y, Xie H, Du X, Wang L, Jin X, Zhang Q, et al. In vivo chemical reprogramming of astrocytes into neurons. Cell Discov. 2021;7(1):12. https://doi.org/10.1038/s41421-021-00243-8

150. Caiazzo M, Giannelli S, Valente P, Lignani G, Carissimo A, Sessa A, et al. Direct conversion of fibroblasts into functional astrocytes by defined transcription factors. Stem Cell Rep. 2015;4(1):25-36. https://doi.org/10.1016/j.stemcr.2014.12.002

151. Karow M, Camp JG, Falk S, Gerber T, Pataskar A, Gac-Santel M, et al. Direct pericyte-to-neuron reprogramming via unfolding of a neural stem cell-like program. Nat Neurosci. 2018;21(7):932-940. https://doi.org/10.1038/s41593-018-0168-3 
